\title{
PERKEMBANGAN WISATA HALAL DI KOREA SELATAN (STUDI KASUS PERSPEKTIF MASYARAKAT INDONESIA DI KOREA SELATAN)
}

\author{
Theresia Avila Rencidiptya Gitanati Firstantin \\ Universitas Gadjah Mada \\ Email: rencidiptya@ugm.ac.id \\ Ummul Hasanah \\ Universitas Gadjah Mada \\ Email: ummul.hasanah@ugm.ac.id
}

\begin{abstract}
The large number of tourists, students, and Muslim migrant workers in South Korea has prompted the South Korean government to start developing various kinds of halal tourism programs. These programs are very interesting and helpful for tourists, students and Muslim migrant workers to visit or live in South Korea. To find out the extent of the development of halal tourism in South Korea, this study was conducted using a descriptive -quantitative method with Indonesian people in South Korea as the object of this research. The object of this study was selected because of the large number of tourists, students, and Indonesian workers in South Korea and the majority of them as Muslim can represent other Muslim communities in South Korea. The results of this study indicate that Muslim-friendly facilities such as halal restaurants, halal food shopping applications, mosques, and prayer rooms in South Korea are quite numerous and scattered in various cities. This is certainly welcomed positively by tourists and the Muslim communities in South Korea. However, there are several things that Korean government still needs to pay attention to, especially related to the socialization of halal food that there is a standardization and process in it.
\end{abstract}

Keywords: Halal Tourism, South Korea, Tourism, Halal Korea, Halal Food

\section{Pendahuluan}

Korea Selatan merupakan salah satu negara tujuan untuk destinasi wisata yang cukup populer beberapa tahun terakhir ini. Popularitas Hallyu (Korean Wave) melalui drama, film, dan musik membuat Korea Selatan menjadi negara yang sangat diminati 
wisatawan untuk dikunjungi. Tidak hanya itu juga, minat pelajar dan pekerja migran untuk tinggal di Korea Selatan juga semakin meningkat. Menurut data Korea Tourism Organisation (2019) pada tahun 2019, jumlah wisatawan asing yang berkunjung ke Korea mencapai 17.5 juta wisatawan. Angka ini merupakan angka tertinggi melampaui capaian angka tertinggi di tahun 2016 sebanyak 17.24 juta wisatawan. Peningkatan data wisatawan asing yang berkunjung ke Korea dapat dilihat melalui tabel berikut.

Tabel 1. Data wisatawan asing berkunjung ke Korea Selatan tahun 2015-2019

(Korea Tourism Organization, 2019)

\begin{tabular}{ll}
\hline Tahun & Jumlah Wisatawan Asing \\
\hline 2015 & 13.23 juta \\
2016 & 17.24 juta \\
2017 & 13.34 juta \\
2018 & 15.35 juta \\
2019 & 17.50 juta \\
\hline
\end{tabular}

Melalui data tabel diatas, dapat terlihat pula peningkatan yang cukup signifikan dari tahun 2018 hingga tahun 2019. Dari peningkatan jumlah wisatawan yang berkunjung ke Korea Selatan, tercatat ada 248 ribu wisatawan Indonesia yang berkunjung dan meningkat sebanyak 12\% pada tahun 2019.

Wisatawan muslim yang berkunjung ke Korea Selatan juga mengalami peningkatan secara signifikan sejak tahun 2016, dan pemerintah Korea Selatan mulai gencar mengembangkan program-program wisata halal yang ramah bagi wisatawan muslim. Hal ini tentunya sangat menarik dan membantu bagi para wisatawan, pelajar, maupun pekerja migran muslim untuk berkunjung maupun tinggal di Korea Selatan. 
Perkembangan program wisata halal yang dilakukan oleh pemerintah Korea meliputi beberapa aspek seperti memperbanyak restoran halal, membuat aplikasi halal korea, dan sebagainya. Program-program ini tentunya mendapatkan respon positif dari banyak pihak dan sangat membantu khususnya bagi para wisatawan muslim.

Melalui penelitian ini diharapkan dapat melihat apakah program-program wisata halal dan fasilitas ramah muslim yang di Korea Selatan ini tersosialisasikan dengan baik, dan hal-hal-hal apa saja yang perlu diperhatikan oleh pemerintah Korea Selatan khususnya dalam proses pengembangan wisata halal ini supaya dapat mengakomodasi kebutuhan masyarakat atau wisatawan Muslim yang ada di Korea Selatan.

\section{Metode Penelitian}

Untuk mengetahui sejauh mana perkembangan wisata halal yang ada di Korea Selatan, penelitian ini menggunakan metode deskriptif kuantitatif dengan masyarakat Indonesia di Korea Selatan sebagai objek penelitian. Objek penelitian ini dipilih karena banyaknya jumlah wisatawan, pelajar dan pekerja Indonesia yang berada di Korea Selatan dan mayoritas beragama muslim dan dapat mewakili masyarakat muslim lainnya di Korea Selatan. Dari kuesioner yang didistribusikan, sebanyak 45 reponden yang bersedia untuk memberikan tanggapan terkait wisata halal di Korea Selatan. 


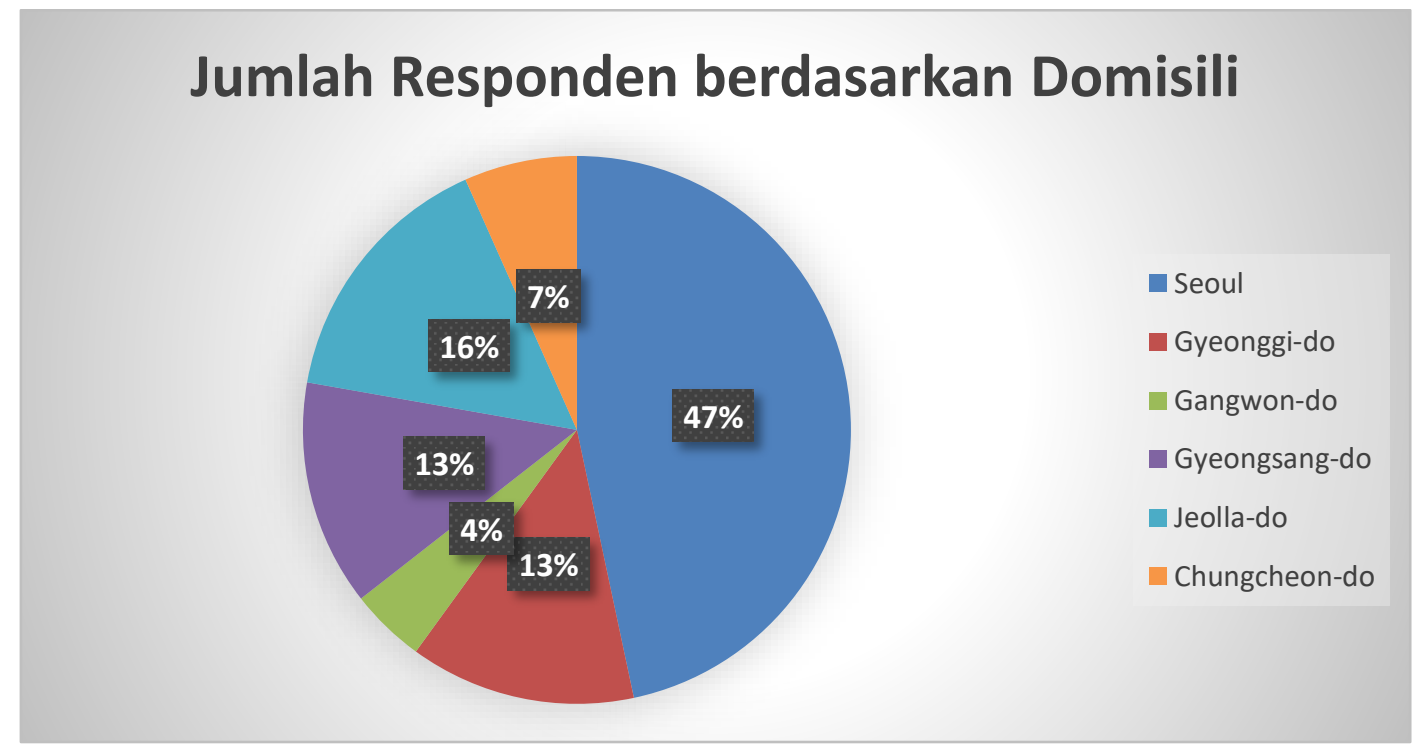

Gambar 1. Jumlah Responden berdasarkan Domisili di Korea Selatan

Melalui Gambar 1 diatas, dari 45 responden masyarakat Indonesia yang menjadi objek penelitian ini, 47\% tinggal di Seoul, 16\% tinggal di Provinsi Jeolla, 13\% tinggal di Provinsi Gyeongsang dan Gyeonggi, dan selebihnya tinggal di Provinsi Gangwon dan Chungcheon. Dari keseluruhan provinsi di Korea Selatan, hanya provinsi Jeju saja yang tidak muncul. Hal ini dikarenakan jarang ada wisatawan asing yang tinggal dalam waktu lama di pulau Jeju. Sebagian besar hanya berkunjung 1-2 hari untuk berlibur. Sedangkan untuk pekerja migran dan pelajar di Korea Selatan semuanya tersebar di berbagai daerah. Dengan keanekaragaman domisili responden, dapat sangat membantu penelitian ini untuk melihat apakah program wisata halal dan fasilitas ramah muslim di Korea Selatan sudah merata dari utara, selatan, barat dan timur Korea Selatan.

Keanekaragaman responden juga terlihat dari profesi dan lamanya tinggal di Korea Selatan. Lebih dari 50\% responden sudah 2-3 tahun tinggal di Korea Selatan dan responden terlama tinggal selama 10 tahun di Korea Selatan. Tidak hanya durasi tinggal saja, profesi dari para responden juga beraneka ragam. Sebagian besar adalah mahasiswa dan pekerja, sedangkan beberapa lainnya adalah ibu rumah tangga. 
Dengan munculnya ragam responden ini, maka pengetahuan dan kebutuhan akan fasilitas dan program ramah muslim juga akan bervariasi. Selain itu, semakin lama durasi responden di Korea Selatan, maka semakin banyak pula pengalaman yang telah dilakukan dan semakin beragam pula pengetahuan yang dimiliki terkait program-program pemerintah Korea yang dicanangkan untuk wisata halal.

\section{Hasil dan Pembahasan}

Dalam penelitian ini akan membagi pembahasan dalam 3 hal, yaitu ketersediaan fasilitas ramah muslim, E-commerce menjadi bagian dari wisata halal, Pekan Restoran Halal Korea dan Aplikasi halal Korea.

\section{Ketersediaan Fasilitas Ramah Muslim}

Masuknya banyak wisatawan muslim ke Korea Selatan baik untuk berwisata maupun tinggal dalam waktu yang cukup lama membuat Pemerintah Korea dalam beberapa tahun terakhir ini berusaha untuk menyediakan berbagai fasilitas ramah muslim seperti rumah makan yang menyediakan makanan halal, tempat ibadah seperti masjid dan mushola, dan tempat berbelanja makanan halal. Pemerintah Korea Selatan memberikan perhatian khusus terhadap wisatawan dan masyarakat muslim yang ada di Korea Selatan seiring dengan meningkatnya wisatawan muslim di Korea Selatan.

Terkait dengan urgensi fasilitas halal yang ramah untuk muslim ini, hampir seluruh dari responden menyatakan bahwa ketersediaan fasilitas tersebut sangatlah penting. Fasilitas ramah muslim yang paling dibutuhkan adalah tempat ibadah dan rumah makan yang menyediakan makanan halal. Dari 45 responden, 64,4\% menyatakan bahwa di sekitar daerah tempat tinggal terdapat rumah makan yang menyediakan makanan halal dan 57,8\% mengetahui bahwa ada supermarket yang menjual makanan atau produk-produk halal. Namun hampir 50\% dari responden 
juga menyatakan bahwa disekitar tempat tinggalnya tidak terdapat rumah makan dan supermarket yang menjual makanan dan produk-produk halal. Prosentase ini menunjukkan bahwa fasilitas rumah makan dan supermarket yang menyediakan makanan halal dapat dikatakan cukup namun belum merata. Hal ini dapat terlihat pada ketidak tersediannya fasilitas tersebut di beberapa daerah domisili responden.

Sedangkan untuk fasilitas ibadah seperti masjid dan mushola, 53,3\% responden menyatakan bahwa tidak ada masjid di sekitar domisili tempat tinggalnya. Namun hal ini berbanding terbalik dengan keberadaan mushola yang ternyata $56,8 \%$ responden menyatakan bahwa ada mushola di sekitar tempat tinggalnya. Melalui hal ini dapat diketahui bahwa ketersediaan tempat ibadah untuk umat muslim di Korea Selatan sudah cukup baik meskipun masih banyak daerah-daerah yang tidak terdapat tempat beribada bagi umat muslim seperti masjid dan mushola.

Ketersediaan fasilitas beribadah yang cukup baik ternyata masih terdapat kendala untuk masyarakat muslim yang tinggal di Korea Selatan ketika ingin menjalankan ibadah. Salah satunya adalah tidak adanya waktu khusus untuk sholat ketika kuliah atau bekerja di Korea Selatan. Hal ini membuat para pelajar dan pekerja harus meminta ijin terlebih dahulu untuk menjalankan ibadah sholat. Selain itu, cukup asing bagi sebagian besar orang Korea melihat pemandangan umat muslim yang menjalankan ibadah sholat di taman, ruang istirahat, dan bahkan di ruang menyusui ketika tidak menemukan mushola atau masjid.

Keberadaan fasilitas beribadah bagi masyarakat dan wisatawan muslim di Korea Selatan tentunya cukup penting mengingat jumlah wisatawan, pelajar dan pekerja migran di Korea Selatan meningkat. Namun beberapa responden mengatakan bahwa tidaklah wajib atau dapat ditoleransi pula jika jumlah fasilitas tempat ibadah bagi masyarakat muslim jumlahnya tidak sebanyak di Indonesia. Hal ini dikarenakan, masyarakat Korea Selatan sendiri beragama Budha dan atheis, dan hanya ada beberapa masyarakat Korea Selatan saja yang muslim. Jumlah fasilitas beribadah 
seperti mushola dan masjid di Korea Selatan yang cukup memadai dan sebanding dengan jumlah masyarakat muslim di Korea Selatan dinilai sudah cukup baik.

\section{E-commerce Menjadi Bagian Program Wisata Halal}

Pada era digital seperti sekarang ini, semua hal dapat dilakukan dengan mudah melalui internet. Mulai dari memudahkan komunikasi jarak jauh, memudahkan dalam proses transaksi melalui e-banking tanpa perlu ke ATM, memudahkan promosi produk dan proses pemesanan barang. Salah satunya adalah e-commerce. E-commerce adalah salah satu peluang bisnis baru dengan proses penyebaran, penjualan, pemasaran produk (barang dan jasa) yang dilakukan secara elektronik dengan memanfaatkan jaringan internet ${ }^{1}$.

Keterbatasan jarak dan jumlah rumah makan maupun supermarket yang menjual makanan halal ini membuat transaksi melalui e-commerce menjadi suatu kebutuhan. Di Korea Selatan, ada beberapa aplikasi e-commerce yang menyediakan produk-produk makanan halal dan berbagai kebutuhan untuk masyarakat muslim. Selain membantu konsumen muslim, produsen juga sangat terbantu dengan penjualan melalui online ini. Proses yang mudah dan cepat membuat e-commerce menjadi pilihan utama.

Melalui data yang didapat dari responden, ada beberapa e-commerce yang menjual produk-produk halal dan ramah muslim yang cukup populer di Korea Selatan. Berdasarkan kepopuleran e-commerce di kalangan warga Indonesia dan masyarakat muslim di Korea lainnya, berikut adalah daftar e-commerce yang menjual produk halal di Korea Selatan.

\footnotetext{
${ }^{1}$ https://pelayananpublik.id/2019/11/28/arti-e-commerce-jenis-manfaat-keuntungan-dankerugiannya/
} 
Tabel 2. E-commerce Populer di Korea Selatan

\begin{tabular}{lll}
\hline No. & E-commerce & Produk \\
\hline 1. & www.yeshalal.co.kr & Daging halal dan makanan instan siap saji \\
2. & albazaarkorea.com & Daging dan makanan halal \\
3. & Bejokorea.com & Bakso halal khas Indonesia \\
4. & Sijangkita.com & Produk-produk makanan Indonesia \\
5. & @albaraka.korea & Daging dan makanan halal
\end{tabular}

Melalui e-commerce di atas, masyarakat muslim di Korea Selatan menjadi lebih mudah mendapatkan pasokan makanan halal dan produk-produk ramah muslim lainnya. Dari kelima e-commerce yang ditunjukan dalam Tabel 2 diatas, www.yeshalal.co.kr merupakan yang paling banyak diketahui oleh masyarakat Indonesia yang ada di Korea dan merupakan web yang paling sering dikunjungi untuk membeli produk-produk halal secara online.

Terlebih lagi, Korea Selatan merupakan salah satu negara yang memiliki akses internet yang tercepat dan budaya pengiriman paket yang dapat dikatakan tercepat. Hal ini dikarenakan, masyarakat Korea sendiri menganut sistem budaya "Palli-palli" atau "cepat-cepat". Budaya ini merupakan budaya yang menjadi ciri khas masyarakat Korea Selatan untuk melakukan segala sesuatu secara cepat. Oleh karena itu, bisnis $e$ commerce di Korea Selatan berkembang sangat pesat dan jumlahnya cukup banyak. Dengan kesibukan masyarakatnya, penjualan produk-produk secara online dinilai sangat membantu masyarakat. Begitu pula masyarakat muslim di Korea Selatan. Kemudahan menemukan makanan dan produk-produk halal secara online tentunya sangat membantu masyarakat muslim yang tidak tahu dimana membeli produkproduk tersebut secara offline. Selain menghemat waktu, konsumen juga tentunya 
dapat langsung melihat produk secara cepat melalui tombol pencarian dan melihat harganya secara jelas tanpa harus menghabiskan waktu untuk mencari-cari secara acak di dalam toko.

Selain dapat membantu konsumen, pelaku usaha e-commerce ini tentunya sangat terbantu dengan adanya aplikasi usaha mereka. Hal ini dikarenakan dapat menghemat biaya karena tidak perlu menyewa tempat dan hanya melakukan promosi secara daring. Promosi usaha ini juga dapat dibilang sangat efektif menarik konsumen dalam jumlah yang lebih besar lagi. Terlebih lagi masyarakat sekarang ini sudah tidak asing dengan penggunaan internet dan kuantitas penggunaan ponsel jauh lebih banyak daripada dulu. Jika dilihat kembali di sekitar kita, hampir semua orang pasti menghabiskan waktunya untuk melihat ponselnya. Hal inilah yang dimanfaatkan oleh pelaku usaha di bidang penjualan produk secara online untuk memasarkan produknya. Dalam hal ini, pelaku usaha dapat memasarkan produknya kepada konsumen di berbagai daerah, konsumen pun dapat terbantu menemukan produk yang dicarinya dan mendapatkan pengiriman barang dalam waktu yang singkat.

\section{Program "Pekan Restoran Halal Korea" dan Aplikasi “Halal Korea"}

Selain melalui pembangunan tempat-tempat ibadah bagi umat muslim di Korea Selatan, Pemerintah Korea Selatan melalui KTO (Korea Tourism Organization) telah melakukan berbagai upaya untuk mendukung dan membantu keberadaan masyarakat muslim yang ada di Korea dengan mengembangkan berbagai program terkait dengan wisata halal. Program-program tersebut diantaranya adalah program "Pekan Restoran Halal Korea" dan juga meluncurkan aplikasi "Halal Korea”.

Program-program ini merupakan program baru yang diinisiasi oleh pemerintah Korea dalam rangka menarik minat wisatawan untuk berkunjung ke Korea Selatan. Dengan adanya program-program ini, diharapkan minat dan antusias 
wisatawan khususnya wisatawan muslim untuk berkunjung ke Korea Selatan semakin meningkat.

1) Program “Pekan Restoran Halal Korea”

Program "Pekan Restoran Halal Korea" ini diselenggarakan sejak akhir 2016 oleh KTO untuk memperkenalkan makanan dan restoran halal di Korea Selatan (Poetri, 2019). Program "Pekan Restoran Halal atau Halal Restaurant Week Korea" ini merupakan acara tahunan yang diselenggarakan untuk memperkenalkan restoran ramah muslim. Namun acara ini diadakan tidak hanya khusus untuk masyarakat muslim di Korea Selatan, namun juga semua wisatawan dari penjuru dunia yang berkunjung ke Korea Selatan. Keunikan dari program ini adalah pengunjung dapat merasakan makanan-makanan halal dari berbagai negara seperti masakan dari Tiongkok, Turki, Italia dan lebih dari 129 restoran halal di Korea Selatan akan ikut serta dalam acara ini. Program ini sendiri juga diadakan selama 35 hari penuh.(Korea Tourism Organization, 2020).

Pada tahun 2020 ini, Halal Restaurant Week Korea 2020 turut serta mengajak 129 restoran halal di Korea Selatan untuk berpartisipasi seperti tahun-tahun sebelumnya. Dalam acara ini, pengunjung tidak hanya dapat menikmati makanan halal saja, namun juga berkesempatan untuk mendapatkan voucher yang akan dibagikan oleh KTO. Voucher-voucher tersebut senilai 3000 KRW, 10.000 KRW dan juga masih banyak keuntungan yang akan didapatkan oleh pengunjung ketika menghadiri acara ini. Dari 129 restoran halal tersebut, KTO pun mengklasifikasikan tingkat kehalalannya sebagai berikut²:

\footnotetext{
${ }^{2}$ Korea Tourism Organisation. (2020). https://hrwkorea.or.kr/info/info.php 


\section{Halal Certified}

Restoran tersebut sudah diakui kehalalannya dan mendapatkan sertifikat halal dari Lembaga Sertifikasi Halal seperti Korea Muslim Federation (KMF).

\section{Self Certified}

Klasifikasi ini ditujukan pada restoran Muslim yang pemiliknya menyatakan bahwa makanan yang dijual adalah makanan halal.

\section{Muslim Friendly}

Restoran ini menjual beberapa makanan halal, namun tidak menutup kemungkinan bahwa mereka juga menjual alkohol.

\section{Pork Free}

Restoran ini tidak menjual makanan halal, namun hanya menjual makanan yang bebas dari penggunaan daging babi. Restoran ini juga memungkinkan menjual minuman beralkohol.

Klasifikasi tingkat kehalalan restoran-restoran ini tentunya sangat membantu masyarakat untuk memilih rumah makan atau restoran sesuai dengan prioritas yang diinginkan. Sehingga hal ini juga dapat menjadi informasi bagi masyarakat muslim khususnya untuk dapat memilih restoran mana yang hendak dimasuki. Dengan adanya klasifikasi ini, masyarakat muslim tidak salah masuk restoran dan tentunya merasa aman dan nyaman untuk makan di restoran yang sesuai dengan yang diinginkan. Karena di Korea Selatan sendiri, banyak orang Korea yang tidak tahu dengan apa yang disebut Halal. Yang mereka ketahui adalah makanan halal berarti makanan yang tidak mengandung daging babi. Sehingga banyak masyarakat muslim yang merasa ragu ketika makan daging di Korea Selatan. Misalnya saja, ketika makan daging sapi pun, masyarakat muslim di Korea Selatan ada beberapa yang makan namun masih ada beberapa yang tidak makan. Hal ini dikarenakan keragu-raguan 
akan kehalalan daging tersebut. Namun jika diberikan klasifikasi seperti itu, akan sangat membantu masyarakat muslim untuk menikmati daging yang prosesnya menerapkan standarisasi halal.

Agenda tahunan yang diadakan oleh pemerintah Korea ini tentunya mendapatkan respon positif dari masyarakat dan wisatawan di Korea Selatan. Namun, hal ini tidak didukung dengan adanya publikasi yang menyeluruh terhadap masyarakat dan wisatawan di Korea Selatan. Hal ini dapat terlihat dalam tabel hasil pengumpulan data dari 45 responden masyarakat Indonesia yang tinggal di Korea Selatan berikut ini.

Tabel 3. Pengetahuan Masyarakat Indonesia terhadap Program Pekan Restoran Halal Korea

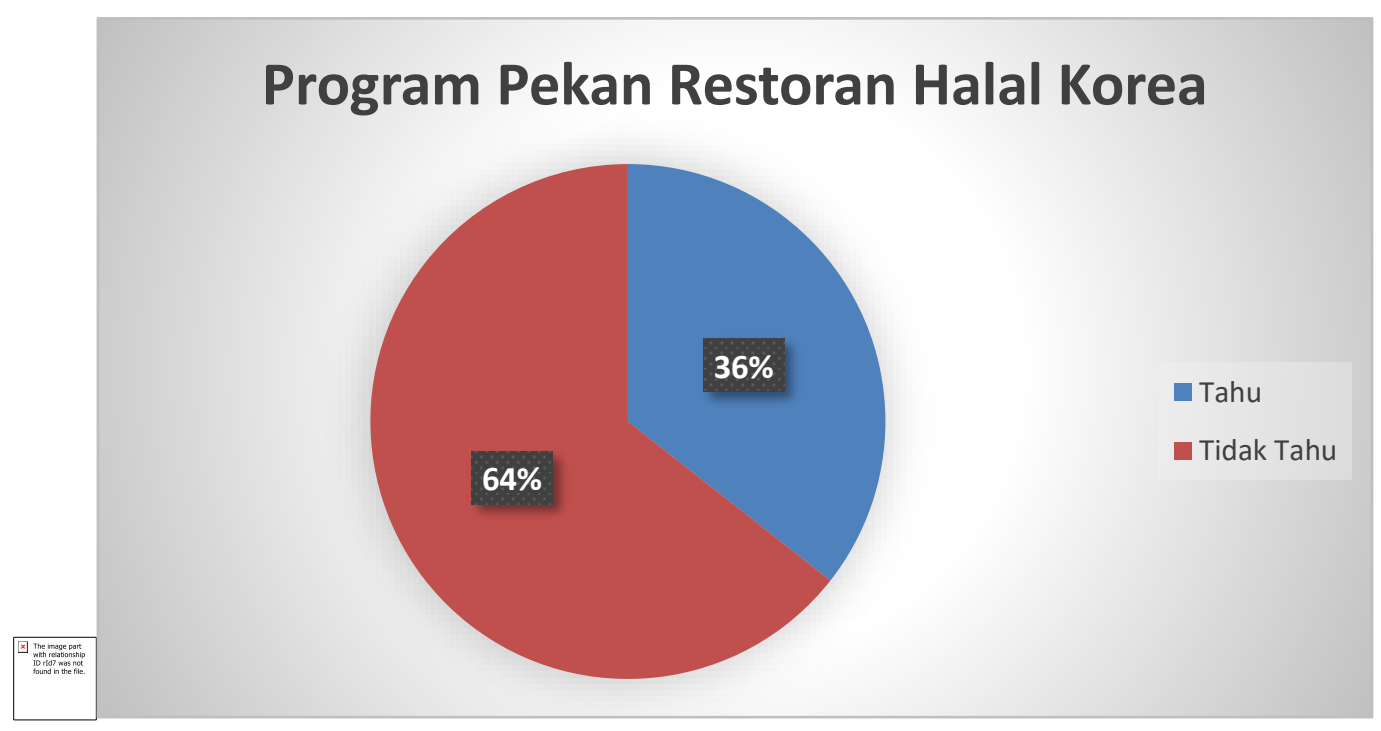

Dari Tabel 3 diatas, sebanyak 64\% responden masyarakat Indonesia di Korea Selatan menyatakan "Tidak Mengetahui" program Pekan Restoran Halal Korea tersebut. Hanya sejumlah 36\% masyarakat Indonesia yang ada di Korea saja yang mengetahuinya. Dengan jumlah lebih dari 50\% responden yang tidak mengetahui adanya program ini, menandakan bahwa program Pekan Restoran Halal Korea yang diadakan oleh Pemerintah Korea melalui Korea Tourism Organization belum 
sepenuhnya diketahui oleh wisatawan maupun orang asing yang tinggal di Korea Selatan.

Program Pekan Restoran Halal Korea ini merupakan program baru yang tentunya akan sangat menarik bagi wisatawan yang berkunjung ke Korea Selatan. Selain sebagai salah satu agenda tahunan, acara ini juga dapat digunakan sebagai tempat pengenalan tentang apa itu makanan halal yang ada di Korea Selatan. Jumlah restoran yang bergabung dalam acara ini tidaklah sedikit dan tentunya memiliki ciri khas sendiri serta menu yang beraneka ragam. Dengan banyaknya wisatawan yang berkunjung ke Korea Selatan, tidak hanya makanan-makanan dari luar negeri saja yang disajikan, namun beberapa restoran juga membuat masakan Korea dalam versi halal. Hal ini tentunya sangat menarik, terlebih lagi bagi wisatawan muslim yang berkunjung ke Korea Selatan pasti ingin mencicipi citarasa khas Korea namun dalam versi halal.

2) Aplikasi "Halal Korea"

Selain program “Pekan Restoran Halal Korea”, pemerintah Korea Selatan juga mengembangkan sebuah aplikasi pencarian makanan halal di Korea Selatan yaitu aplikasi "Halal Korea”. Bertepatan dengan Olimpiade Musim Dingin di Pyeongchang pada Februari 2018, pemerintah Korea saat itu mentargetkan akan ada 1,2 juta turis muslim yang akan datang ke Korea Selatan. Oleh karena hal tersebut, maka pemerintah Korea Selatan melalui MAFRA (Korean Ministry of Argiculture, Food, and Rular Affairs) bekerjasama dengan Global Halal membuat aplikasi pencarian fasilitas ibadah dan tempat makan halal bagi wisatawan muslim yang berkunjung ke Korea Selatan. ${ }^{3}$

\footnotetext{
${ }^{3}$ https://www.idntimes.com/travel/destination/putriana-cahya/liburan-halal-ke-korea/full
} 


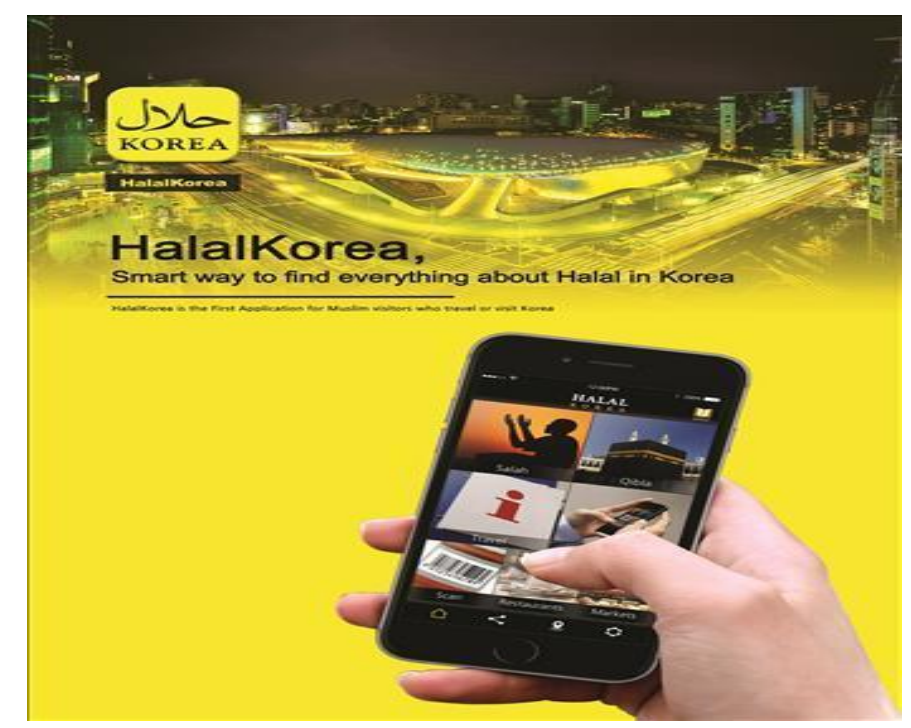

Gambar 2. Aplikasi Halal Korea (1)

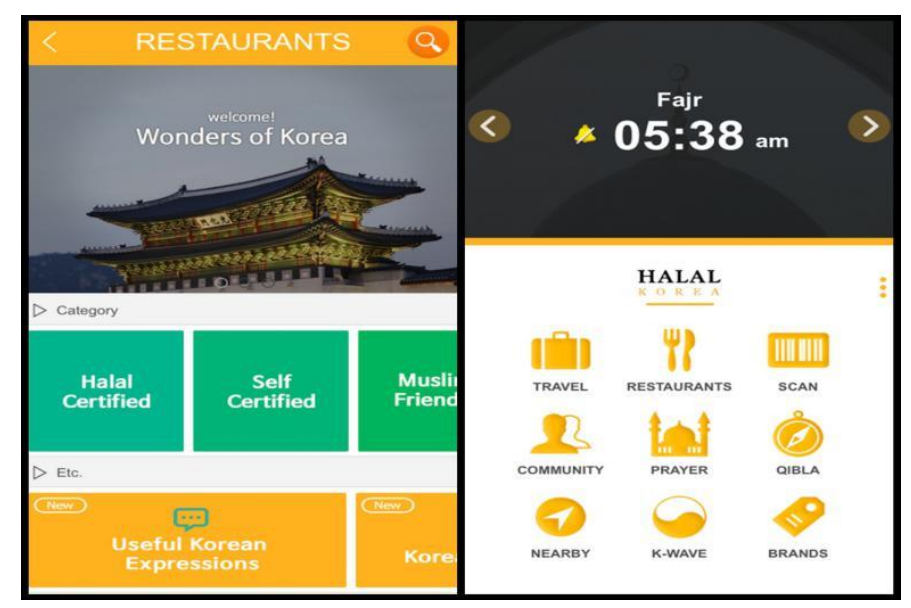

Gambar 3. Aplikasi Gambar Korea (2)

Melalui aplikasi "Halal Korea" ini, diharapkan dapat membantu wisatawan muslim yang sedang berkunjung ke Korea Selatan menjadi dimudahkan dalam mencari tempat makan dan tempat beribadah. Aplikasi tersebut juga menyediakan fasilitas Bahasa Indonesia. Hal ini tentunya sangat membantu wisatawan Indonesia yang berkunjung ke Korea dengan jumlah yang terus bertambah setiap tahunnya. 
Namun sama halnya dengan Program "Pekan Restoran Halal Korea”, keberadaan aplikasi "Halal Korea" ini juga tidak banyak diketahui oleh wisatawan asing khususnya masyarakat Indonesia di Korea Selatan.

Tabel 5. Pengetahuan Masyarakat Indonesia terhadap Aplikasi Halal Korea

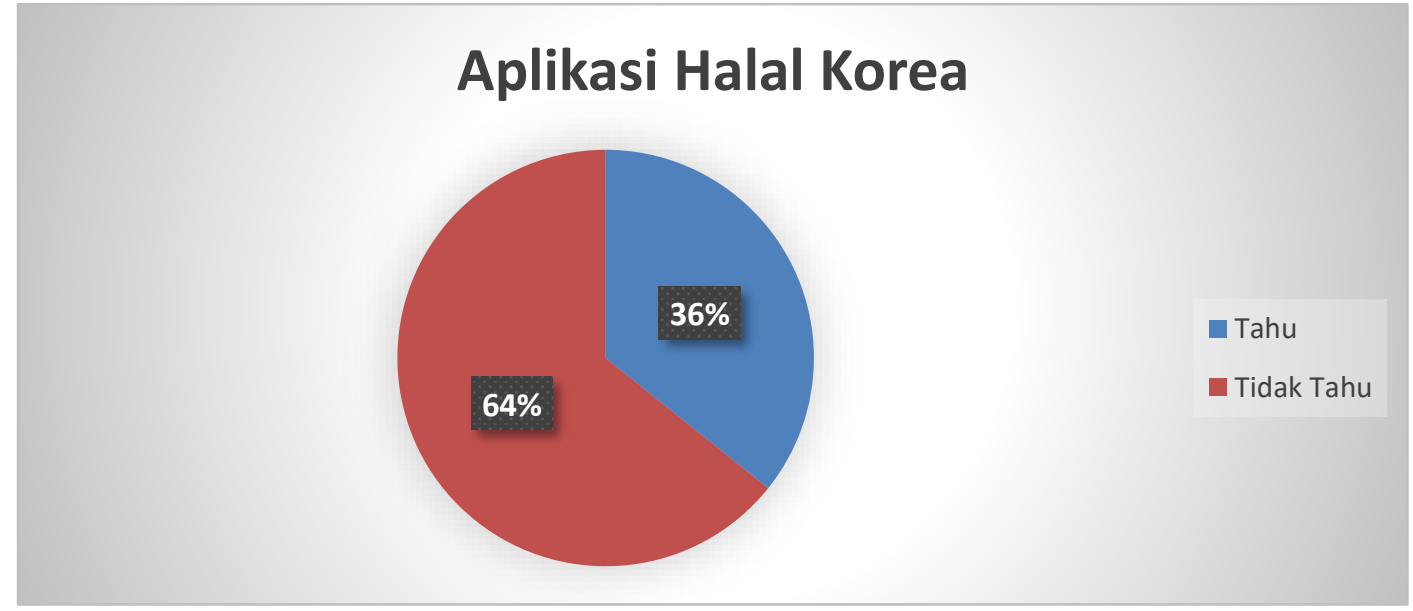

Melalui tabel 5 diatas, sebanyak $64 \%$ responden menyatakan bahwa tidak mengetahui keberadaan dari aplikasi "Halal Korea" dan hanya "36\%" responden mengetahui dan menggunakannya. Melalui hal ini dapat disimpulkan bahwa Aplikasi Halal Korea belum banyak diketahui oleh wisatawan dan perlu diadakannya sosialisasi lebih lagi terhadap pengenalan Aplikasi Halal Korea supaya aplikasi ini berfungsi secara efektif dalam membantu wisatawan muslim khususnya.

Aplikasi Halal Korea ini merupakan aplikasi baru yang jika dipromosikan dengan baik dan gencar tentunya akan sangat banyak masyarakat muslim di Korea Selatan menggunakan aplikasi ini. Namun, ternyata masih banyak orang yang tidak mengetahui dan belum menggunakan aplikasi ini. Cukup disayangkan aplikasi bagus seperti ini belum banyak digunakan di Korea Selatan. Hal ini perlu dijadikan perhatian khusus bagi pemerintah Korea Selatan untuk dapat mengevaluasi promosi program-program yang dibuat supaya dapat tersampaikan pada masyarakat umum. 


\section{Kesimpulan}

Kesimpulan yang dapat diambil melalui penelitian terkait Perkembangan Wisata Halal di Korea Selatan ini adalah pemerintah Korea Selatan sudah sangat serius dalam mengembangkan wisata halal di negaranya. Dengan adanya fasilitasfasilitas ramah muslim seperti masjid, mushola dan rumah makan sudah cukup banyak dan cukup tersebar di beberapa wilayah di Korea Selatan dan cukup membantu masyarakat dan umat muslim khususnya wisatawan asing selama di Korea Selatan. Karena selama ini, kesulitan terbesar masyarakat muslim adalah mencari tempat ibadah. Hal ini dikarenakan berbeda dengan masyarakat yang beragama non-muslim, masyarakat muslim memiliki aturan beribadah yang minimal 5 waktu dalam sehari dan merupakan kewajiban. Oleh karena itu, ketersediaan tempat ibadah merupakan hal yang paling penting bagi masyarakat muslim dimana pun berada. Namun dispensasi bagi pekerja atau pelajar muslim untuk melaksanakan ibadah juga perlu dipertimbangkan. Beberapa pekerja dan pelajar masih ada yang mengeluhkan bahwa di tempat mereka berada, masih cukup sulit untuk beribadah karena tidak adanya dispensasi khusus ditengah jam kerja aupun jam kuliah.

Selain itu, program pemerintah yang sedang dikembangkan untuk memfasilitasi wisatawan muslim di Korea Selatan seperti Program Pekan Restoran Halal dan Aplikasi Halal Korea perlu mendapatkan perhatian khusus, terlebih terkait dengan sosialisasi program-program tersebut yang belum merata sehingga banyak wisatawan asing dan masyarakat asing di Korea Selatan belum dapat menikmati dan memanfaatkan program-program ini. Selain itu, sosialisasi terkait makanan halal terhadap warga Korea Selatan yang membuka rumah makan ramah muslim dapat lebih ditingkatkan. Hal ini disebabkan oleh banyaknya masyarakat Korea Selatan yang tidak tahu kriteria halal itu sendiri seperti apa. Banyak pemilik rumah makan yang masih berpikir bahwa makanan halal itu adalah makanan tanpa daging babi saja, padahal didalamnya terdapat standar khusus apa yang disebut dengan makanan 
halal bagi warga muslim mulai dari proses pemotongan hewan dan perlengkapan yang digunakan.

Sejauh ini, usaha yang dilakukan oleh pemerintah Korea Selatan dalam meningkatkan daya tarik wisatawan muslim untuk berkunjung ke Korea Selatan sudah sangat baik. Berbagai fasilitas dibangun, dan akses wisatawan muslim memperoleh makanan halal pun semakin dipermudah. Hal ini sangat perlu untuk diapresiasi. Namun sosialisasi program-program tersebut sangatlah diperlukan karena sampai saat ini sosialisasi program-program pemerintah Korea dirasa masih kurang.

\section{Ucapan Terima Kasih}

Terimakasih kepada semua pihak yang terlah berkontribusi dalam penelitian ini. Kepada Sekolah Vokasi UGM atas bantuan materi sehingga penelitian ini berjalan dengan lancar, Departemen Bahasa Seni dan Manajemen Budaya atas dukungan dalam proses kelengkapan dokumen, peneliti dan mahasiswa atas bantuan pikiran serta tenaga untuk dapat menyelesaikan penelitian ini. Terlebih pula diucapkan terimakasih kepada para responden penelitian ini yang telah meluangkan waktunya untuk menjawab setiap pertanyaan yang diperlukan dalam penelitian ini.

\section{Daftar Pustaka}

Cahya, Putriana. (2017, November 26). Sudah Tahu Aplikasi yang Membantu Liburan Halal Ke Korea ini? Retrieved from https://www.idntimes.com/travel/destination/putriana-cahya/liburan-halalke-korea/full

Fraenkel, Jack. R and Norman E. Wallen. (1990). How to Design and Evaluate Research in Education USA. San Fransisco State University. 
Hasmiyarti, Afriza. (2019). Strategi Pemerintah Korea Selatan dalam Diplomasi Publik di Bidang Pariwisata Studi Kasus : Wisata Ramah Muslim di Korea Selatan. Skripsi. Universitas Islam Indonesia. Retrieved from dspace.uii.ac.id.

Korea Tourism Organization. (2016). Muslim-friendly Restaurant in Korea. Korea Tourism Organisation. Retrieved from https://www.visitkorea.or.id/halal_restaurant

Korea Tourism Organization. (2020). Retrieved from https://hrwkorea.or.kr/info/info.php

Kusumaningrum, D. N., Fairuz, A. M., Putri, E. P., \& Amalia, E. P. (2017). Trend Pariwisata Halal Korea Selatan. Senaspro, 978-979. Retrieved from http://research-report.umm.ac.id/index.php/researchreport/article/viewFile/1307/1525

May, F.A., Ayu, A., \& Aulia, N. (2020). Wisata Halal Trend Baru Industri Pariwisata Korea Selatan. Jurnal Penelitian, 14, 153-165. Retrieved from https://www.researchgate.net/publication/344092409_Wisata_Halal_Trend_Ba ru_Industri_Pariwisata_Korea_Selatan

My Sharing. (2015). Mencari Makanan Halal di Korea kini jadi Mudah dengan HALAL Korea. Retrieved from http://mysharing.co/mencari-makanan-halal-di-koreakini-jadi-mudah-dengan-halal-korea/

Sakinah, Kiki. (2020). Pekan Restoran Halal Korea Tampilkan Tema Halal di Youtube. Retrevied from https://republika.co.id/berita/qge25o430/pekan-restoran-halalkorea-tampilkan-tema-halal-di-youtube

Poetri, T.R.L., (2019). Implementasi Pengembangan Halal Tourism di Korea Selatan. Skripsi thesis, Universitas Airlangga. Retrieved from http://repository.unair.ac.id/83500/

Rezeki, Sri., Arianti, Gusmia. (2018). Praktik Publik Relation di Era Distruptif : Pariwisata Halal Korea Selatan dalam Meningkatkan Daya Saing di Era Distruptif. Yogyakarta: Penerbit Galuh Patria.

The Food and Beverage News. (2015). Hallal App for Muslim in Korea. Retrieved from https://www.thinkfood.co.kr/news/articleView.html?idxno=65506

Yeonhap News. (2017).S. Korea pins hopes on halal foods to woo Muslim tourists. Retrieved from https://en.yna.co.kr/view/AEN20170907010900320

Yeonhap News. (2019). Over 1 million Muslim tourists to visit S. Korea this year. Retrieved from https://en.yna.co.kr/view/AEN20190915000700320 


\section{Profil Penulis}

Theresia Avila Rencidiptya Gitanati Firstantin, S.S., M.A., adalah dosen Prodi D4 Bisnis Perjalanan Wisata, Sekolah Vokasi, Universitas Gadjah Mada. Menempuh pendidikan S1 Bahasa Korea di Universitas Gadjah Mada Yogyakarta (2014) dan menyelesaikan pendidikan S2 Teaching Korean as a Foreign Language di Kookmin University, Seoul, Korea Selatan (2019). Selama kuliah, aktif bekerja paruh waktu dalam bidang perjalanan wisata baik di Indonesia maupun Korea Selatan. Penulis juga memiliki spesialisasi di bidang bahasa, budaya dan pariwisata Korea. Selain mengajar, Rencidiptya juga aktif melakukan penelitian dan pengabdian masyarakat khususnya di bidang pariwisata dan bahasa Korea, serta penulisan buku dan modul yang berkaitan dengan Bahasa dan Kebudayaan Korea.

Ummul Hasanah, S.S., M.A adalah seorang pengajar di Prodi D3 Bahasa Korea, Departemen Bahasa, Seni, dan Manajemen Budaya, Sekolah Vokasi UGM sejak tahun 2014. Menempuh pendidikan S1 di bidang Sastra Inggris di UGM (2011), Yogyakarta dan pendidikan S2 di Chulalongkorn University, Bangkok, Thailand di bidang Korean Studies (2013). Ummul Hasanah memiliki spesialisasi di bidang bahasa dan budaya Korea, bahasa Inggris, budaya kerja Korea, dan budaya pop Korea. Sepanjang karirnya sebagai dosen di UGM, aktif melakukan kegiatan pengajaran, penelitian, pengabdian kepada masyarakat, penulisan buku, dan penulisan modul yang berkaitan dengan Korean Studies dan pengajaran bahasa asing. 